\title{
Review \\ Sex Differences, Genetic and Environmental Influences on Dilated Cardiomyopathy
}

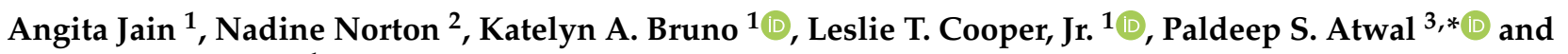 \\ DeLisa Fairweather ${ }^{1, *}$ \\ 1 Department of Cardiovascular Medicine, Mayo Clinic, 4500 San Pablo Road, Jacksonville, FL 32224, USA; \\ jain.angita@mayo.edu (A.J.); bruno.katelyn@mayo.edu (K.A.B.); cooper.leslie@mayo.edu (L.T.C.J.) \\ 2 Department of Cancer Biology, Mayo Clinic, 4500 San Pablo Road, Jacksonville, FL 32224, USA; \\ norton.nadine@mayo.edu \\ 3 Genomic and Personalized Medicine, Atwal Clinic, 214 Brazilian Avenue, Suite 230, Palm Beach, \\ FL 33480, USA \\ * Correspondence: dra@atwalclinic.com (P.S.A.); fairweather.delisa@mayo.edu (D.F.); \\ Tel.: +1-904-953-6740 (D.F.); Fax: +1-904-953-7117 (D.F.)
}

Citation: Jain, A.; Norton, N.; Bruno, K.A.; Cooper, L.T., Jr.; Atwal, P.S.; Fairweather, D. Sex Differences, Genetic and Environmental Influences on Dilated Cardiomyopathy. J. Clin. Med. 2021, 10, 2289. https://doi.org/10.3390/ jcm10112289

Academic Editor: Martina Calore

Received: 31 March 2021

Accepted: 18 May 2021

Published: 25 May 2021

Publisher's Note: MDPI stays neutral with regard to jurisdictional claims in published maps and institutional affiliations.

Copyright: (c) 2021 by the authors. Licensee MDPI, Basel, Switzerland. This article is an open access article distributed under the terms and conditions of the Creative Commons Attribution (CC BY) license (https:// creativecommons.org/licenses/by/ $4.0 /)$.

\begin{abstract}
Dilated cardiomyopathy (DCM) is characterized by dilatation of the left ventricle and impaired systolic function and is the second most common cause of heart failure after coronary heart disease. The etiology of DCM is diverse including genetic pathogenic variants, infection, inflammation, autoimmune diseases, exposure to chemicals/toxins as well as endocrine and neuromuscular causes. DCM is inherited in $20-50 \%$ of cases where more than 30 genes have been implicated in the development of DCM with pathogenic variants in TTN (Titin) most frequently associated with disease. Even though male sex is a risk factor for heart failure, few studies have examined sex differences in the pathogenesis of DCM. We searched the literature for studies examining idiopathic or familial/genetic DCM that reported data by sex in order to determine the sex ratio of disease. We found 31 studies that reported data by sex for non-genetic DCM with an average overall sex ratio of 2.5:1 male to female and 7 studies for familial/genetic DCM with an overall average sex ratio of 1.7:1 male to female. No manuscripts that we found had more females than males in their studies. We describe basic and clinical research findings that may explain the increase in DCM in males over females based on sex differences in basic physiology and the immune and fibrotic response to damage caused by mutations, infections, chemotherapy agents and autoimmune responses.
\end{abstract}

Keywords: dilated cardiomyopathy; familial dilated cardiomyopathy; idiopathic dilated cardiomyopathy; sex differences; sex ratio; pathogenesis; environment; virus; genes

\section{Introduction}

Dilated cardiomyopathy (DCM) is characterized by dilatation of the left ventricle and impaired systolic function. The American Heart Association classifies DCM as genetic, mixed or acquired, whereas the European Society of Cardiology classifies DCM as genetic (familial) or non-genetic (non-familial) [1]. The World Health Organization (WHO) defines DCM as a serious cardiac disorder in which structural or functional abnormalities of the heart muscle can lead to substantial morbidity and mortality owing to complications such as heart failure and arrhythmia [1]. DCM is the second most common cause of heart failure after coronary heart disease, with an estimated prevalence of 1 in $250-500$ people [2]. The etiology of DCM is diverse including pathogenic genetic variants, infection, inflammation, autoimmune diseases, exposure to toxins as well as endocrine or neuromuscular causes [3]. DCM presents between the ages of 20-60 but can occur in children or the elderly. DCM often has a long latency period and patients can be clinically asymptomatic.

After identifying systolic dysfunction and a morphologically enlarged left ventricle, an etiological assessment is undertaken and, if no identifiable cause (except genetic) can be 
found, a clinical diagnosis of 'idiopathic DCM' is assigned [3]. Idiopathic cardiomyopathy is likely influenced by an individual's genetic profile and environmental factors. If an individual had DCM from an environmental factor, like chemotherapy, their DCM would not be considered to be idiopathic. DCM is considered to be familial when more than one first-degree relative has been diagnosed with DCM or has had sudden cardiac death at a young age [2]. DCM is inherited in $20-50 \%$ of cases and abnormalities are seen frequently on echocardiogram in asymptomatic relatives [3]. Inheritance of idiopathic DCM is primarily autosomal dominant, although other modes of inheritance have been observed. DCM can also occur secondary to or in conjunction with systemic disease or syndromes. Determining the precise molecular etiology responsible for familial DCM impacts medical management and allows early identification of those at increased risk [3]. In contrast to many Mendelian disorders, genetic associations present in familial cardiomyopathies have variable penetrance, and manifestations might also result from multiple low penetrance alleles or additional genes with a modifying (perhaps protective) effect on severity or age of onset, or when exposure to an additional insult occurs [4]. We also note the existence of sporadic cases of DCM that may result from multiple low penetrance alleles within the population [5]. The identification of the pathogenic variant(s) might have important complex trait predictive and therapeutic implications.

\section{Sex Differences}

Sex-specific differences in genes are known to exist in the hearts of healthy men and women $[6,7]$. Male sex is an important risk factor for developing heart failure in a number of cardiovascular conditions including DCM [8,9]; however, few clinical studies have examined sex differences in incidence or pathogenetic mechanisms in DCM specifically. One study found that men with DCM had more apoptosis-related protein expression compared to women [10]. Additionally, men with myocarditis/acute DCM present with almost a twofold greater incidence of myocardial fibrosis compared to women using cardiac MRI [11,12], with fibrosis being implicated as an important factor in the pathogenesis of DCM. Sex differences observed in DCM have been attributed primarily to the effect of sex hormones on cardiac resident cells and cardiac inflammation [13] and multiple mouse models lacking estrogen receptors have demonstrated that estrogen improves cardiac function [14-16]. The major steroid hormones that have been studied in cardiovascular diseases and the immune response to cardiac damage or infection are estrogens, testosterone and progesterone. These so-called sex hormones bind to nuclear-associated receptors in cardiac cells like cardiomyocytes and fibroblasts where they influence gene expression. Estrogen receptor alpha $(E R \alpha)$ and beta $(E R \beta)$ and the androgen receptor $(A R)$ are sequestered in the cytoplasm bound to heat shock proteins. When activated by ligand, they bind directly to estrogen response elements (EREs) or androgen response elements (ARE) in the promoter region of specific genes or indirectly activate gene transcription by binding transcription factors $[17,18]$. Many of the genes that are influenced by estrogen/ERE in the heart are known to promote reparative remodeling rather than fibrosis, which is a primary factor that leads to dilatation and heart failure.

Whenever damage occurs to the heart from genetic and/or environmental causes, immune cells are recruited to the heart. Sex steroids alter immune cell function via nuclear and non-nuclear membrane expression of hormone receptors. Signaling through membrane hormone receptors is more rapid than nuclear receptors and can result in both gene transcription through initiation of kinase signal pathways or in non-transcriptional signals via calcium flux and activation of glutamate receptors [18-20]. The mechanisms of how estrogen protects against cardiomyopathy are not fully understood, but mouse models of cardiomyopathy lacking the estrogen receptor show increased expression of cardiac calcium channels [21].

The American Heart Association scientific statement on DCM published in 2016 concluded that the overall effect of female sex on heart failure, and DCM especially, was not clear at that time and that women may be underrepresented in clinical trials [22] 
as is observed from registries found in Table 1 that show fewer women than men in studies of DCM. Even though it is quite likely that women are underrepresented in clinical trials of DCM, another explanation for the observation is that the number of men and women recruited to studies generally represents a sex difference in presentation of the disease similar to what has been found to occur for other cardiovascular and autoimmune diseases $[23,24]$. The EuroHeart Failure Survey II found that DCM occurred more often in males than females [25]. An estimate of DCM prevalence was derived from a populationbased study conducted in Olmstead County, Minnesota that reported a male to female sex ratio of 3:1 [26]. However, there is a lack of data in the literature on whether sex differences exist in phenotype, severity and/or outcomes for most epidemiological studies of DCM $[25,27,28]$. For this review, we queried PubMed using the search terms "sex/gender and cardiomyopathy" and "sex/gender differences and idiopathic dilated cardiomyopathy" to identify studies reporting DCM by sex. We found 1229 studies in our search; however, many studies were rejected for reasons that included the sex not being reported in the study, which was a frequent finding in our search, and the study not distinguishing the type of cardiomyopathy (Figure 1). Additionally, we did not include types of DCM in this analysis that occur in only one sex such as peripartum cardiomyopathy.

Table 1. Sex ratio in studies of DCM ${ }^{\mathrm{a}, \mathrm{b}}$.

\begin{tabular}{|c|c|c|c|c|c|c|}
\hline Year of Publication & Patients $(n)$ & Male:Female ( $n$ ) & Sex Ratio (M:F) & $\begin{array}{l}\text { Mean Age of } \\
\text { Patients }\end{array}$ & Additional Information & References \\
\hline 1949 & 35 & $25: 10$ & $2.5: 1$ & - & \multirow[b]{2}{*}{$\begin{array}{c}\text { Coxsackievirus heart } \\
\text { disease }\end{array}$} & [27] \\
\hline 1968 & 22 & $13: 9$ & $1.4: 1$ & - & & [28] \\
\hline 1980 & 164 & 109:55 & 1.9:1 & - & $\begin{array}{c}\text { Coxsackievirus } \\
\text { myocarditis progressing } \\
\text { to DCM }\end{array}$ & [29] \\
\hline 1984 & 41 & $27: 14$ & $1.9: 1$ & - & DCM & [30] \\
\hline 1987 & 72 & $59: 13$ & $4.5: 1$ & $50 \pm 15$ & DCM & [31] \\
\hline 1990 & 201 & $163: 38$ & $4.2: 1$ & $48 \pm 11$ & DCM & [32] \\
\hline 1992 & 225 & 163:62 & $2.6: 1$ & $41 \pm 12.3$ & DCM & [33] \\
\hline 1993 & 303 & $238: 65$ & $3.6: 1$ & & Idiopathic DCM & [34] \\
\hline 1994 & 128 & $68: 60$ & $1.1: 1$ & 59 & DCM & [35] \\
\hline 1995 & 441 & $309: 132$ & 2.3:1 & $43 \pm 13$ & DCM & [36] \\
\hline 1996 & 144 & $118: 26$ & $4.5: 1$ & $39 \pm 10.4$ & Nonischemic DCM & [37] \\
\hline 2000 & 131 & $108: 23$ & $4.7: 1$ & $52 \pm 12$ & DCM & [38] \\
\hline 2004 & 458 & $326: 132$ & $2.4: 1$ & 58.3 & Nonischemic DCM & [39] \\
\hline 2004 & 56 & $42: 14$ & $3: 1$ & $50.3 \pm 2.2$ & DCM & [40] \\
\hline 2005 & 20 & $14: 6$ & 2.3:1 & $46.5 \pm 10$ & Recent onset CM & [10] \\
\hline 2008 & 54 & $38: 16$ & $2.3: 1$ & - & $\begin{array}{c}\text { DCM in elderly ( } 65-83 \\
\text { years of age) }\end{array}$ & {$[41]$} \\
\hline 2010 & 43 & $29: 13$ & $2.2: 1$ & - & $\begin{array}{c}\text { Idiopathic DCM with new } \\
\text { onset HF }\end{array}$ & {$[42]$} \\
\hline 2010 & 115 & 100:35 & $1.5: 1$ & - & DCM & [43] \\
\hline 2011 & 373 & $230: 143$ & $1.6: 1$ & $45 \pm 14$ & & {$[44]$} \\
\hline 2012 & 95 & $52: 43$ & $1.2: 1$ & - & $\begin{array}{l}95 \text { DCM patients vs. } 95 \\
\text { healthy subjects }\end{array}$ & [45] \\
\hline $2013^{c}$ & 603 & 440:163 & $2.7: 1$ & - & Idiopathic DCM & [46] \\
\hline 2013 & 96 & $66: 30$ & $2.2: 1$ & $53 \pm 11.6$ & DCM & [47] \\
\hline 2014 & 373 & $230: 143$ & $1.6: 1$ & $45 \pm 14$ & DCM & [48] \\
\hline 2014 & 853 & 614:239 & $2.5: 1$ & $45 \pm 15$ & Idiopathic DCM & [49] \\
\hline 2015 & 213 & $128: 85$ & $1.5: 1$ & - & DCM & [50] \\
\hline 2015 & 639 & $405: 212$ & $1.9: 1$ & - & DCM & [51] \\
\hline 2015 & 16,091 & 11,059:5032 & 2.2:1 & $48.3 \pm 12.6$ & DCM UNOS Database & [52] \\
\hline 2018 & 881 & 591:290 & $2: 1$ & $52 \pm 15$ & DCM & [53] \\
\hline 2018 & 52 & $40: 12$ & 3.3:1 & $57.2 \pm 7$ & Non-ischemic DCM & [54] \\
\hline 2018 & 1260 & 935:325 & 2.8:1 & - & CM Registry-DCM & [55] \\
\hline 2019 & 35 & $24: 11$ & 2.1:1 & - & DCM with/without $\mathrm{PH}$ & [56] \\
\hline
\end{tabular}

a Abbreviations: CM Registry, cardiomyopathy registry for the EURObservational Research Programme (used DCM data); DCM, dilated cardiomyopathy; F, female; HF, heart failure; M, male; PH, pulmonary hypertension. ${ }^{b}$ Some overlap exists in these studies which include genetic and other causes of DCM. ${ }^{c}$ Five studies with largest number of patients (over 500) are highlighted in bold in the table. 
A

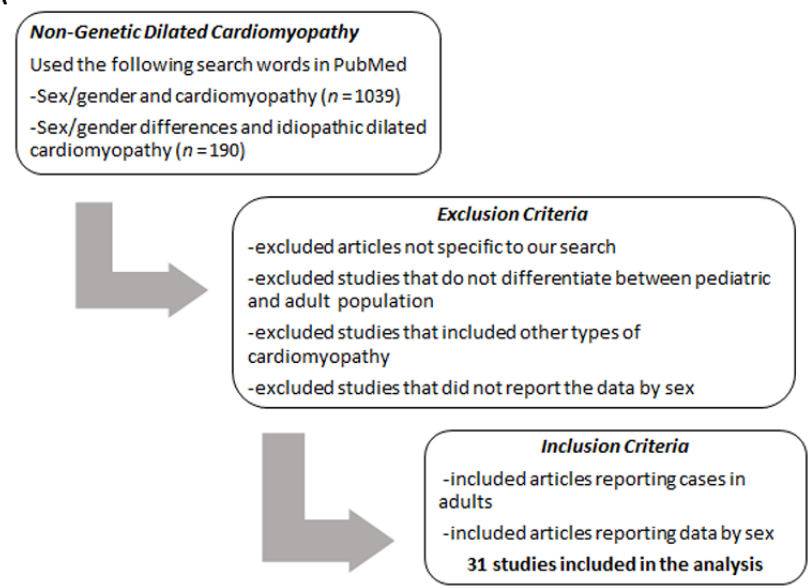

B

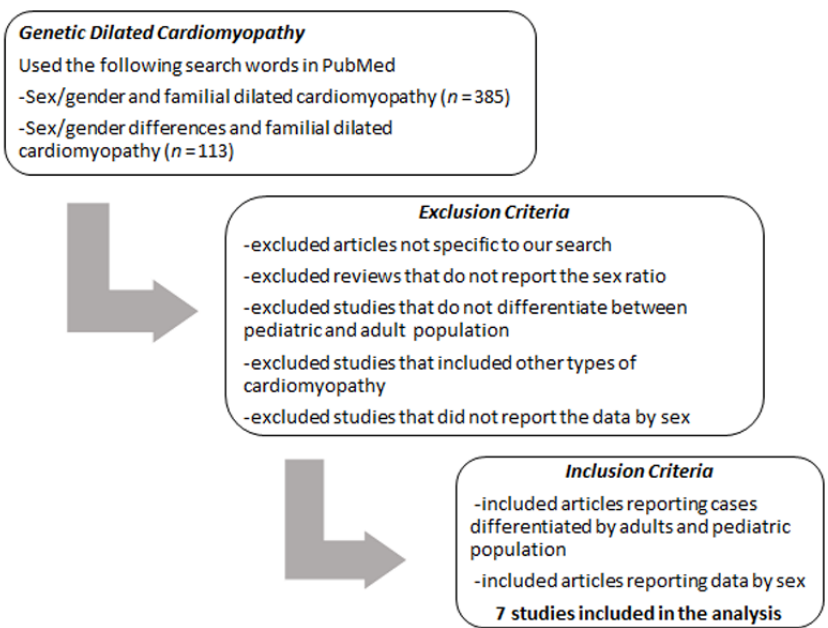

Figure 1. Study Flowchart. (A) Non-genetic dilated cardiomyopathy vs. (B) genetic dilated cardiomyopathy.

After exclusions, 31 studies were selected for the analysis of sex ratios in DCM from all causes (Table 1, Figure 1A). Table 1 includes data from adults with DCM from all causes such as viral and idiopathic DCM. The largest study from our search that reported data by sex was the United Network of Organ Sharing (UNOS) registry database, which identified 16,091 patients with DCM where 11,059 were males and 5032 females-a sex ratio of 2.2:1 men to women (Table 1).

The multinational cardiomyopathy registry of the EURObservational Research Programme is a prospective, observational study published in 2018 comprised of 1260 patients with DCM out of a total of 3208 patients [55]. They examined 935 males and 325 females in their study, which is a sex ratio of 2.8:1 (Table 1). A study of 881 patients with DCM where 591 were males and 290 females indicated a sex ratio of 2:1 men to women [53]. Another study with 853 patients with DCM included 614 males and 239 females, which makes a sex ratio of 2.5:1 men to women [49]. We highlight these studies because they have a larger sample size than the other studies listed in Table 1. It is important to emphasize that these studies were not designed to examine sex differences and the number of men and women simply reflect the number of patients recruited to the registries or clinical studies. However, even with this caveat these data are the best indicator of the sex differences in DCM. Of note, none of the studies reported more women than men with DCM in the study. Overall, the five studies with numbers of patients with DCM over 500 from our search (bold in Table 1) generated an average sex ratio of 2.4:1 men to women. The overall combined average sex ratio for DCM in adults from all 31 studies combined was 2.5:1 men to women.

\section{Role of Genes}

In DCM, the cardiac muscle becomes thin and weakened causing the ventricular chamber to become enlarged so that the heart is unable to pump blood efficiently. For the heart to maintain cardiac output, the ventricular volume increases while contractility is reduced, producing the thin walled, dilated appearance that is characteristic of DCM. More than 30 genes have been implicated in the development of DCM through genome-wide linkage analyses, [57] candidate gene sequencing [58] and genetic association studies [59] and can be grouped into four major categories: proteins forming the myocyte cytoskeleton, sarcomeric proteins, nuclear envelope proteins and calcium homeostasis and mitochondrial function regulators [60]. Most familial DCM has an autosomal dominant inheritance pattern; however, other inheritance patterns have been identified including autosomal recessive, $x$-linked, mitochondrial and polygenic [59]. The most common gene in which DCM-associated variants are found is the TTN (Titin) gene [61], the largest known gene in humans and the third most prevalent in muscle. This gene encodes for the structural protein of the sarcomere and is prevalent in $12-25 \%$ of DCM cases (higher percentage in 
familial cases). Other genes commonly associated with DCM include variants in LMNA (Lamin A/C), MYH7 ( $\beta$-myosin heavy chain), MYH6 ( $\alpha$-myosin heavy chain) and BAG3. Table 2 lists the genes most associated with DCM $[1,2,51,57,62,63]$. Several of these genes have been found to be associated with myocarditis (some with confirmed viral etiologies) in adults and children that may predispose them to developing cardiomyopathy after viral infection including DYS (dystrophin), BAG3 (BAG family molecule chaperone regulator), DSP (desmoplakin), PKP2 (plakophilin-2), RYR2 (ryanodine recepter-2), SCN5A (sodium ion channel) or TNNI3 (cardiac troponin I) [64-66]. Clinical and animal model evidence exists that myocarditis can progress to DCM in susceptible individuals $[44,67-70]$.

Table 2. Most common genes involved in DCM (in descending order).

\begin{tabular}{|c|c|c|c|}
\hline Gene & Encoding Protein & Function of the Protein & References \\
\hline TTN & Titin & Forms the structure of the sarcomere & [61] \\
\hline LMNA & Lamin A/C & Nuclear membrane envelope & [71] \\
\hline MYH7 & Beta-myosin heavy chain & Sarcomere & [57] \\
\hline MYH6 & Alpha myosin heavy chain & Sarcomere & [57] \\
\hline$B A G 3$ & BAG family molecular chaperone regulator & Chaperone-assisted selective autophagy & {$[72,73]$} \\
\hline$M Y P N$ & Myopalladin & Z-disc in the sarcomere & [74] \\
\hline$D S P$ & Desmoplakin & Desmosome & [75] \\
\hline FLNC & Filamin C & Functions at $Z$ discs & [76] \\
\hline RBM20 & RNA- binding protein 20 & Spliceosome, RNA-binding protein & [77] \\
\hline TTNT2 & Cardiac Troponin $\mathrm{T}$ & Sarcomere & [57] \\
\hline SCN5A & Sodium ion channel & Ion channel & {$[78,79]$} \\
\hline TTNC1 & Cardiac Troponin C & Sarcomere & [57] \\
\hline TTNI3 & Cardiac Troponin I & Sarcomere & [57] \\
\hline TPM1 & Alpha- Tropomyosin & Sarcomere & {$[58,80]$} \\
\hline
\end{tabular}

The locus heterogeneity and the role of genes on disease progression is predicted to affect both sexes equally [81]. However, large scale genome-wide association studies attributing genetic profiles to disease risk have demonstrated significant sex differences [82]. These findings may be explained by the pathophysiology and pathogenesis of DCM where genetic (both rare and common variants with different modes of transmission, modifying and epigenetic factors) and environmental factors (infections or toxins that damage cardiac tissue and promote inflammation) may both contribute to disease severity, progression, age at onset and response to cardiac medication (Figure 2) [60].

Haddad et al. [83] observed sex differences in gene expression of patients with idiopathic DCM. 55 genes, mainly involved in energy metabolism and transcription regulators, were found to be differentially expressed in females compared to males (37 upregulated and 18 downregulated) while only 19 of those genes were expressed in males (13 upregulated and 7 downregulated) [83]. The dysregulated genes in males were related to myocardial contraction. Gene expression leading to ventricular remodeling were upregulated in both sexes. Sex-specific differences can be important indicators of disease progression and potentially used as diagnostic markers or as drug targets of heart failure in men and women [83]. Studies of familial DCM due to troponin T or titin mutations demonstrate a difference in phenotype in adult males (more severe) compared to females [61,84]. 


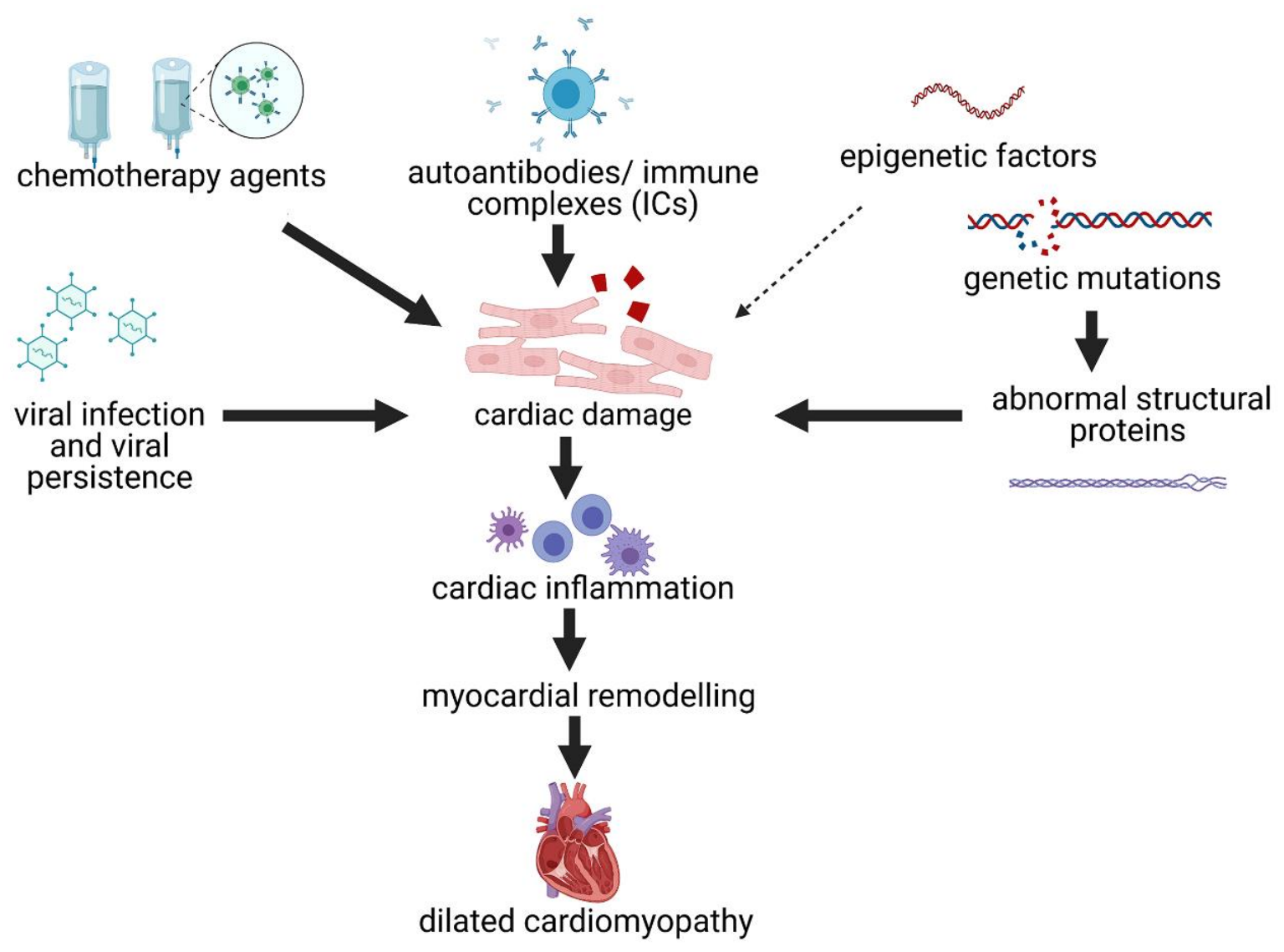

Figure 2. Hypothesis of interplay between genes and environment in the progression to DCM. A number of different insults can damage the myocardium initiating an immune response that leads to remodeling, fibrosis and ultimately to dilation of the ventricles and DCM. These include mutations that alter cardiac proteins, viral infections, autoantibodies, immune complexes (ICs) and toxins in the form of chemotherapy agents. (Created with BioRender.com, accessed on 31 March 2021).

Next, we queried PubMed using the search terms "familial dilated cardiomyopathy" and "sex and gender differences in familial dilated cardiomyopathy" to find articles that reported genetic DCM by sex. We found 498 studies in our search; however, many studies were rejected for reasons that included the sex not being reported in the study and the study not examining genetic DCM (Figure 1). We found seven studies and two review articles that described data by sex or reported sex differences in familial/genetic DCM (Table 3). We have included one study with a pediatric population (reporting 216 adults and 129 children) because of the large number of patients in the study and because there are very few studies reporting data on genetic DCM [85]. This was the only study that had similar numbers of males and females and a similar sex ratio (Table 3), which may have been influenced by children being included in the study. The largest study comprising 492 familial DCM adult patients had a sex ratio of 1.7:1 males to females (Table 3) [52]. The average sex ratio of the five studies that had at least 300 patients with familial DCM was 1.3:1 males to females (bold in Table 3). 
Table 3. Sex ratio in studies of familial DCM ${ }^{\mathrm{a}}$.

\begin{tabular}{|c|c|c|c|c|c|c|}
\hline $\begin{array}{c}\text { Year of } \\
\text { Publication }\end{array}$ & Patients $(n)$ & Male:Female & Sex Ratio (M:F) & Mean Age of Patients & $\begin{array}{c}\text { Mode of } \\
\text { Inheritance }\end{array}$ & References \\
\hline 1989 & 45 & $33: 12$ & $2.7: 1$ & 54 & & [26] \\
\hline $1999^{b}$ & 345 & 169:176 & $0.97: 1$ & $\begin{array}{c}\text { Adults }(38.3 \pm 14) \text { and } \\
\text { children }(<16 \text { years } \\
\text { of age })\end{array}$ & $\mathrm{AD}$ & [85] \\
\hline 2006 & 304 & 173:131 & $1.3: 1$ & - & $\begin{array}{l}\text { AD (most } \\
\text { common) }\end{array}$ & [86] \\
\hline 2012 & 312 & 208:104 & $2: 1$ & $48.6 \pm 13.0$ & & [61] \\
\hline 2013 & 418 & 233:185 & 1.3:1 & $46 \pm 13$ & & [87] \\
\hline 2015 & 492 & 311:181 & $1.7: 1$ & $42.1 \pm 13.1$ & & [52] \\
\hline 2017 & 72 & $48: 24$ & $2: 1$ & 34 & $\mathrm{AD}(\mathrm{TTN}+/-)$ & [88] \\
\hline
\end{tabular}

a Abbreviations: AD, autosomal dominant; AR, autosomal recessive; F, female; M, male; TTN, titin. ${ }^{\mathrm{b}}$ Five studies with largest number of patients (over 300) are highlighted in bold in the table.

The sex ratio reported for familial DCM in both of the review articles was 1.5:1 males to females $[89,90]$, but what studies the data were obtained from is not clear from the articles. The average sex ratio of familial DCM from all seven studies that we examined in this review of the literature was 1.7:1 males to females, the same as the largest study [52].

\section{Pathogenesis of DCM}

Damage to the myocardium that occurs from gene defects, viral infection or chemicals recruits immune cells to the heart in order to repair the damage. Myocardial biopsy samples or autopsies from patients with DCM have demonstrated the presence of inflammatory cell infiltrates and/or gene expression profiles indicating immune cell activation [91,92]. Known causes of inflammatory DCM include infections and autoimmunity (Figure 2) [93]. Infections, particularly viral infections like coxsackievirus B3 and parasites like Trypanasoma cruzi (Chagas disease), are known to cause acute cardiac inflammation or myocarditis that progresses to DCM in humans and animal models [93-95]. Viral infection or damaged self with adjuvant activates the complement cascade and CD11b/complement receptor (CR)3 on immune cells in animal models [96,97], and studies in humans and animal models have found that the primary factor that drives the progression from myocarditis to DCM is complement activation [97,98]. TLR4 on mast cells and macrophages increase the proinflammatory and profibrotic cytokine IL-1 $\beta$ that promotes fibrosis [99-101]. A T helper 1 (Th1)-type immune response associated with interferon (IFN)- $\gamma$ prevents remodeling and progression to DCM after myocarditis, while Th2- (IL-4 and IL-33-associated cytokines) and Th17-type (IL-17A and IL-6-associated cytokines) immune responses promote remodeling, fibrosis and DCM in mouse models and human studies [68,102-109]. Cardiac specific autoantibodies that are associated with viral and autoimmune myocarditis are able to deposit as immune complexes (ICs) with complement on cardiac tissue including the pericardium and further promote damage, inflammation and fibrosis [97,100,110-114]. Remodeling genes are upregulated in the heart during acute viral myocarditis during the peak of inflammation (day 10 after infection), but fibrosis only appears in the heart several weeks later after inflammation has largely subsided (day 35 after infection) [101]. Thus, fibrotic scar tissue eventually replaces the damaged tissue, leading to stiffening of the heart, dilatation and progression to heart failure in susceptible individuals (Figure 2).

DCM also occurs secondary to chemotherapy for cancer. The number of patients diagnosed with DCM secondary to antiblastic drugs is rising, due to the increasing age of the general population and the increase in survival times, attributed to the success of earlier diagnosis and new therapies [115]. DCM can be the final phase of a pathological process that is usually defined more broadly as chemotherapy-related cardiac dysfunction (CRCD). CRCD is reported to affect up to $10 \%$ of cancer survivors [116]. There are two types of cardiotoxicity- reversible myocardial dysfunction that is independent of the drug dose and irreversible myocardial damage that occurs due to a cumulative dose of the drug. The 
exact mechanism leading to DCM is unclear and it is believed that damage occurs through the generation of reactive oxygen species, accumulation of anthracycline metabolites that disrupt sarcomere structure and function and mitochondrial dysfunction $[117,118]$. These processes lead to cardiac remodeling and ultimately, dilation of the heart giving rise to DCM. Whether inflammation is involved in this process is less clear because cardiac biopsies are not routinely obtained from these patients and there are not good animal models to replicate the pathogenesis of disease.

\section{Sex Differences in Genetic DCM}

As mentioned previously, the locus heterogeneity and the role of genes on disease progression is predicted to affect both sexes equally yet sex differences exist in genetic DCM. So, why does DCM from genetic causes occur more often in men when it would be expected to occur at a similar rate in men and women? First, it is important to understand that underlying sex differences in tissue physiology influence cardiac function in a sexspecific manner even in healthy, normal hearts and influence how the heart and immune system respond to injury or infection. Sex hormone receptors such as ER $\alpha / \beta, A R$ and aromatase, the enzyme that converts androgens to estrogens, are expressed both on/in cardiac tissues as well as on/in cells of the immune system [8,10,45,46,119]. Estrogen and androgen receptors are expressed within vascular endothelial cells, vascular smooth muscle cells, cardiac fibroblasts and cardiomyocytes in humans and rodents [8,10,45,46,119]. Additionally, sex hormone receptors may be expressed at different levels by sex; females express higher levels of ERs in their arteries for example and men have higher levels of testosterone in their heart than females $[46,47,119]$. These underlying sex differences contribute to differences in cardiac physiology by sex. Even though there were only a handful of studies of familial/genetic DCM that reported the number of men and women in their study that we were able to find in our PubMed search (Table 3), these studies reported a higher number of men with DCM compared to women similar to studies of DCM from all causes (Table 1). More familial studies of patients with DCM need to be conducted to determine whether a sex ratio of 1.5:1 to 1.7:1 male to female remains consistent and whether a greater sex difference is observed with general DCM (2.5:1 male to female) or whether there is essentially no difference in the sex ratio between the two categories of DCM (i.e., all causes/non-genetic vs. genetic) once more patients are examined. A meta-analysis needs to be conducted once more studies have been performed to determine the statistical significance of the sex ratio and if the ratio is lower in genetic cases of DCM when compared to non-genetic cases. A couple of studies of genetic DCM have reported similar numbers of males and females affected but adverse events occurred earlier in male than female carriers indicating a clear sex-difference [61,120].

The second point is that physical damage to the heart that occurs from genetic causes (i.e., pathogenic variants in titin), damage from toxins (i.e., chemotherapy agents like doxorubicin) and/or infections (i.e., coxsackievirus) is most likely going to activate an immune response to the damage and if it does, that immune response will be sex specific. Sex hormone receptors are located on/in many cells of the immune system including T cells, B cells, monocytes, macrophages, dendritic cells (DCs) and mast cells (MCs) in humans and rodents [55,120]. Importantly, only monocyte/macrophages and mast cells have both nuclear and membrane ERs and the AR $[55,120]$. MCs are critically important cells that drive sex-specific differences in response to cardiac damage by acting as antigen presenting cells (APCs), degranulating in response to infections or toxins/chemicals and initiating immune responses through TLRs and other innate immune receptors [112,121-123]. Mast cells also play a central role in mediating cardiac remodeling that leads to DCM by releasing other factors like enzymes such as serpin A3n ( $\alpha 1$-antichymotrypsin) that cleave/activate profibrotic cytokines such as interleukin (IL)-1 $\beta$ and TGF- $\beta 1$ to their active form and MMPs [101]. $17 \beta$-estradiol has been found to mediate a protective effect in response to cardiac damage, regardless of the cause of the damage, by reducing apoptosis in cardiac myocytes, reactive oxygen species-induced cardiac damage and preventing cardiac hypertrophy and 
fibrosis [120-123]. Estrogen has been found to decrease proinflammatory TLR4-induced cytokine expression of IL-1 $\beta$, IL-6, TNF $\alpha$ from monocyte/macrophages [124]. TLR4 and these proinflammatory cytokines have been found to promote remodeling and fibrosis that leads to DCM in patients and animal models of myocarditis [101,125], which occurs more often in males than females [12]. Estrogen inhibits neutrophil infiltration, oxidant stress and necrosis in an ER-dependent manner following ischemia/reperfusion. TNF $\alpha$ levels increase in ovariectomized rats that have reduced circulating estrogen levels when subjected to ischemia that reverses when estrogen is restored [126]. Aside from inflammation that comes into the heart in response to cardiac injury (i.e., mutation altered protein structure, viral damage, toxin damage with chemotherapy), sex hormones alter cardiac function by binding to androgen and estrogen receptors on cardiac vascular endothelial cells, smooth muscle cells, fibroblasts and myocytes $[13,98,110]$. ER $\beta$ has been found to inhibit reactive oxygen species-mediated NF-қB inflammation [127]. In contrast, testosterone activated the NF-қB pathway leading to an increase in inflammation and hypertrophy $[12,122,123,128]$.

\section{Genetics and Environment}

Genetic variants that alter the structure of proteins in the heart increase the risk for developing cardiomyopathy/DCM. However, some variants may not appear until an environmental pressure such as an infection or toxin/chemical inflicts damage, which may increase the risk for progression to chronic cardiomyopathy or more severe disease and heart failure in these individuals. This may partly explain why common viral infections like coxsackieviruses lead to cardiac inflammation and heart failure in only a small number of individuals compared to the nearly $100 \%$ infectivity rate for the virus. Similarly, genetic background may increase the risk for cardiomyopathy at lower chemotherapy (i.e., anthracycline) doses than for individuals without mutations. If an interplay occurs between environmental factors and genetic variations, then gene variants could be used to predict risk of developing cardiomyopathy following cardiac damage. These patients might be sensitive to anthracyclines independent of the dose given [129]. Early identification of cardiac damage would be important to intervene to prevent remodeling and progression to DCM and heart failure. Sera biomarkers like troponins and NTpro-BNP are routinely monitored to identify cardiac damage, yet they may only be effective at detecting more severe cardiac damage as occurs with myocardial infarct. They are often less effective at detecting mild myocardial damage from a viral infection, for example, that can none-the-less still progress to DCM. There remains a need to find more sensitive methods to detect risk of progression to DCM.

\section{Limitations}

Limitations to the study include using only PubMed to search for articles. Additionally, we searched PubMed for articles using "sex and gender" as terms, but we do not discuss the influence of gender on the progression of DCM. We did not conduct a formal 'meta-analysis' to determine whether the sex ratio obtained from the manuscripts reporting men and women with idiopathic or non-genetic DCM were significantly different from those with genetic DCM, primarily because there are so few genetic DCM studies reporting data by sex. We also did not examine or discuss sex differences in pediatric DCM. Finally, although genetic defects and environmental factors like viruses and chemicals (chemotherapy agents) are able to cause DCM, the cause of most cases seen in the clinic remain unknown or idiopathic.

\section{Conclusions and Future Directions}

Sex differences occur in DCM for all causes including familial/genetic, with more males developing disease than females. However, there is a need for clinical and basic research studies that investigate the mechanisms behind the sex differences. Additionally, it is critical that studies report data according to sex (and age) in order to better understand the progression of disease in both sexes. This will enable biomarker discovery and therapeutic 
targets in the future and personalized management of patients. Based on what is known about the pathogenesis of DCM, we postulate that if biopsies were taken from genetic and idiopathic cases of DCM there would be evidence of inflammation, fibrosis and remodeling of the damaged tissue similar to the pathological changes that have been observed during viral myocarditis/acute DCM. Yet there are still many unanswered questions and further research is needed to deepen our understanding of the pathogenesis of disease.

Author Contributions: Conceptualization, A.J., D.F. and P.S.A.; methodology, A.J. and D.F.; writingoriginal draft preparation, A.J., N.N., K.A.B., L.T.C.J., P.S.A. and D.F.; writing-review and editing, A.J., N.N., K.A.B., L.T.C.J., P.S.A. and D.F.; funding acquisition, D.F. All authors have read and agreed to the published version of the manuscript.

Funding: This study was supported by grants from the NIH (R21 AI145356, R21 AI152318, R21 AI154927), the American Heart Association (20TPA35490415), the For Elysa Foundation and the Myocarditis Foundation to D.F. The sponsors were not involved in the study design, collection, analysis or interpretation of data, in writing the manuscript or in the decision to submit the article for publication.

Institutional Review Board Statement: The study was a review of the literature and did not require IRB review.

Informed Consent Statement: Informed consent was not required for this study.

Data Availability Statement: All data are available within the manuscript.

Conflicts of Interest: K.A.B. is a past director of communications and secretary to the board of directors of the Myocarditis Foundation and is currently secretary to the scientific advisory board, L.T.C.J. is a current member of the board of the Myocarditis Foundation and D.F. is a past member of the board and a current scientific advisory member of the Myocarditis Foundation.

\section{References}

1. Schultheiss, H.P.; Fairweather, D.; Caforio, A.L.P.; Escher, F.; Hershberger, R.E.; Lipshultz, S.E.; Liu, P.P.; Matsumori, A.; Mazzanti, A.; McMurray, J.; et al. Dilated cardiomyopathy. Nat. Rev. Dis. Primers 2019, 5, 32. [CrossRef] [PubMed]

2. Hershberger, R.E.; Hedges, D.J.; Morales, A. Dilated cardiomyopathy: The complexity of a diverse genetic architecture. Nat. Rev. Cardiol. 2013, 10, 531-547. [CrossRef] [PubMed]

3. Dellefave, L.; McNally, E.M. The genetics of dilated cardiomyopathy. Curr. Opin. Cardiol. 2010, 25, 198-204. [CrossRef]

4. Rosenbaum, A.N.; Agre, K.E.; Pereira, N.L. Genetics of dilated cardiomyopathy: Practical implications for heart failure management. Nat. Rev. Cardiol. 2020, 17, 286-297. [CrossRef] [PubMed]

5. Norton, N.; Robertson, P.D.; Rieder, M.J.; Zuchner, S.; Rampersaud, E.; Martin, E.; Li, D.; Nickerson, D.A.; Hershberger, R.E.; National Heart, L.; et al. Evaluating pathogenicity of rare variants from dilated cardiomyopathy in the exome era. Circ. Cardiovasc. Genet. 2012, 5, 167-174. [CrossRef] [PubMed]

6. Isensee, J.; Ruiz Noppinger, P. Sexually dimorphic gene expression in mammalian somatic tissue. Gend. Med. 2007, 4 (Suppl. B), S75-S95. [CrossRef]

7. Isensee, J.; Witt, H.; Pregla, R.; Hetzer, R.; Regitz-Zagrosek, V.; Noppinger, P.R. Sexually dimorphic gene expression in the heart of mice and men. J. Mol. Med. 2008, 86, 61-74. [CrossRef]

8. Cleland, J.G.; Swedberg, K.; Follath, F.; Komajda, M.; Cohen-Solal, A.; Aguilar, J.C.; Dietz, R.; Gavazzi, A.; Hobbs, R.; Korewicki, J.; et al. The EuroHeart Failure survey programme-A survey on the quality of care among patients with heart failure in Europe. Part 1: Patient characteristics and diagnosis. Eur. Heart J. 2003, 24, 442-463. [CrossRef]

9. Luchner, A.; Bröckel, U.; Muscholl, M.; Hense, H.W.; Döring, A.; Riegger, G.A.; Schunkert, H. Gender-specific differences of cardiac remodeling in subjects with left ventricular dysfunction: A population-based study. Cardiovasc. Res. 2002, 53, 720-727. [CrossRef]

10. Sheppard, R.; Bedi, M.; Kubota, T.; Semigran, M.J.; Dec, W.; Holubkov, R.; Feldman, A.M.; Rosenblum, W.D.; McTiernan, C.F.; McNamara, D.M.; et al. Myocardial expression of fas and recovery of left ventricular function in patients with recent-onset cardiomyopathy. J. Am. Coll. Cardiol. 2005, 46, 1036-1042. [CrossRef]

11. Cocker, M.; Friedrich, M.G. Cardiovascular magnetic resonance of myocarditis. Curr. Cardiol. Rep. 2010, 12, 82-89. [CrossRef] [PubMed]

12. Cocker, M.S.; Abdel-Aty, H.; Strohm, O.; Friedrich, M.G. Age and gender effects on the extent of myocardial involvement in acute myocarditis: A cardiovascular magnetic resonance study. Heart 2009, 95, 1925-1930. [CrossRef] [PubMed]

13. Regitz-Zagrosek, V.; Kararigas, G. Mechanistic Pathways of Sex Differences in Cardiovascular Disease. Physiol. Rev. 2017, 97, 1-37. [CrossRef] [PubMed] 
14. Gabel, S.A.; Walker, V.R.; London, R.E.; Steenbergen, C.; Korach, K.S.; Murphy, E. Estrogen receptor beta mediates gender differences in ischemia/reperfusion injury. J. Mol. Cell Cardiol. 2005, 38, 289-297. [CrossRef] [PubMed]

15. Skavdahl, M.; Steenbergen, C.; Clark, J.; Myers, P.; Demianenko, T.; Mao, L.; Rockman, H.A.; Korach, K.S.; Murphy, E. Estrogen receptor-beta mediates male-female differences in the development of pressure overload hypertrophy. Am. J. Physiol Heart Circ. Physiol. 2005, 288, H469-H476. [CrossRef]

16. Devanathan, S.; Whitehead, T.; Schweitzer, G.G.; Fettig, N.; Kovacs, A.; Korach, K.S.; Finck, B.N.; Shoghi, K.I. An animal model with a cardiomyocyte-specific deletion of estrogen receptor alpha: Functional, metabolic, and differential network analysis. PLoS ONE 2014, 9, e101900. [CrossRef]

17. Fox, H.S.; Bond, B.L.; Parslow, T.G. Estrogen regulates the IFN-gamma promoter. J. Immunol. 1991, 146, $4362-4367$.

18. Buskiewicz, I.A.; Huber, S.A.; Fairweather, D. Sex hormone receptor expression in the immune system. In Sex Differences in Physiology; Academic Press: Amsterdam, The Netherlands, 2016; pp. 45-60.

19. Benten, W.P.; Lieberherr, M.; Stamm, O.; Wrehlke, C.; Guo, Z.; Wunderlich, F. Testosterone signaling through internalizable surface receptors in androgen receptor-free macrophages. Mol. Biol. Cell 1999, 10, 3113-3123. [CrossRef]

20. Benten, W.P.; Lieberherr, M.; Giese, G.; Wrehlke, C.; Stamm, O.; Sekeris, C.E.; Mossmann, H.; Wunderlich, F. Functional testosterone receptors in plasma membranes of T cells. FASEB J. 1999, 13, 123-133. [CrossRef]

21. Johnson, B.D.; Zheng, W.; Korach, K.S.; Scheuer, T.; Catterall, W.A.; Rubanyi, G.M. Increased expression of the cardiac L-type calcium channel in estrogen receptor-deficient mice. J. Gen. Physiol. 1997, 110, 135-140. [CrossRef]

22. Bozkurt, B.; Colvin, M.; Cook, J.; Cooper, L.T.; Deswal, A.; Fonarow, G.C.; Francis, G.S.; Lenihan, D.; Lewis, E.F.; McNamara, D.M.; et al. Current diagnostic and treatment strategies for specific dilated cardiomyopathies: A scientific statement from the American Heart Association. Circulation 2016, 134, e579-e646. [CrossRef] [PubMed]

23. Batton, K.A.; Austin, C.O.; Bruno, K.A.; Burger, C.D.; Shapiro, B.P.; Fairweather, D. Sex differences in pulmonary arterial hypertension: Role of infection and autoimmunity in the pathogenesis of disease. Biol. Sex. Differ. 2018, 9, 15. [CrossRef] [PubMed]

24. Brandt, J.E.; Priori, R.; Valesini, G.; Fairweather, D. Sex differences in Sjogren's syndrome: A comprehensive review of immune mechanisms. Biol. Sex. Differ. 2015, 6, 19. [CrossRef] [PubMed]

25. Nieminen, M.S.; Harjola, V.P.; Hochadel, M.; Drexler, H.; Komajda, M.; Brutsaert, D.; Dickstein, K.; Ponikowski, P.; Tavazzi, L.; Follath, F.; et al. Gender related differences in patients presenting with acute heart failure. Results from EuroHeart Failure Survey II. Eur J. Heart Fail. 2008, 10, 140-148. [CrossRef] [PubMed]

26. Codd, M.B.; Sugrue, D.D.; Gersh, B.J.; Melton, L.J. Epidemiology of idiopathic dilated and hypertrophic cardiomyopathy. A population-based study in Olmsted County, Minnesota, 1975-1984. Circulation 1989, 80, 564-572. [CrossRef] [PubMed]

27. Ludden, T.E.; Edwards, J.E. Carditis in poliomyelitis; an anatomic study of 35 cases and review of the literature. Am. J. Pathol. 1949, 25, 357-381.

28. Sainani, G.S.; Krompotic, E.; Slodki, S.J. Adult heart disease due to the Coxsackie virus B infection. Medicine 1968, 47, 133-147. [CrossRef]

29. Woodruff, J.F. Viral myocarditis. A review. Am. J. Pathol. 1980, 101, 425-484.

30. Bagger, J.P.; Baandrup, U.; Rasmussen, K.; Møller, M.; Vesterlund, T. Cardiomyopathy in western Denmark. Br. Heart J. 1984, 52, 327-331. [CrossRef]

31. Ikram, H.; Williamson, H.G.; Won, M.; Crozier, I.G.; Wells, E.J. The course of idiopathic dilated cardiomyopathy in New Zealand. Br. Heart J. 1987, 57, 521-527. [CrossRef]

32. Komajda, M.; Jais, J.P.; Reeves, F.; Goldfarb, B.; Bouhour, J.B.; Juillieres, Y.; Lanfranchi, J.; Peycelon, P.; Geslin, P.; Carrie, D. Factors predicting mortality in idiopathic dilated cardiomyopathy. Eur. Heart J. 1990, 11, 824-831. [CrossRef] [PubMed]

33. Sachero, A.; Casazza, F.; Recalcati, F.; de Maria, R.; Preti, L.; Mattioli, R.; Ferrari, F.; Capozzi, A.; Camerini, F. Clinical and prognostic significance of echocardiographic parameters in dilated cardiomyopathy: A prospective study on 225 patients. The Italian Multicenter Study of Cardiomyopathies Group. G. Ital. Cardiol. 1992, 22, 1077-1090. [PubMed]

34. De Maria, R.; Gavazzi, A.; Recalcati, F.; Baroldi, G.; De Vita, C.; Camerini, F. Comparison of clinical findings in idiopathic dilated cardiomyopathy in women versus men. The Italian Multicenter Cardiomyopathy Study Group (SPIC). Am. J. Cardiol. 1993, 72, 580-585. [CrossRef]

35. Coughlin, S.S.; Gottdiener, J.S.; Baughman, K.L.; Wasserman, A.; Marx, E.S.; Tefft, M.C.; Gersh, B.J. Black-white differences in mortality in idiopathic dilated cardiomyopathy: The Washington, DC, dilated cardiomyopathy study. J. Natl. Med. Assoc. 1994, $86,583-591$.

36. Gavazzi, A.; De Maria, R.; Porcu, M.; Beretta, L.; Casazza, F.; Castelli, G.; Luvini, M.; Parodi, O.; Recalcati, F.; Renosto, G. Dilated cardiomyopathy: A new natural history? The experience of the Italian Multicenter Cardiomyopathy Study (SPIC). G. Ital. Cardiol. 1995, 25, 1109-1125.

37. Grzybowski, J.; Bilińska, Z.T.; Ruzyłło, W.; Kupść, W.; Michalak, E.; Szcześniewska, D.; Poplawska, W.; Rydlewska-Sadowska, W. Determinants of prognosis in nonischemic dilated cardiomyopathy. J. Card. Fail. 1996, 2, 77-85. [CrossRef]

38. Fauchier, L.; Babuty, D.; Cosnay, P.; Poret, P.; Rouesnel, P.; Fauchier, J.P. Long-term prognostic value of time domain analysis of signal-averaged electrocardiography in idiopathic dilated cardiomyopathy. Am. J. Cardiol. 2000, 85, 618-623. [CrossRef] 
39. Kadish, A.; Dyer, A.; Daubert, J.P.; Quigg, R.; Estes, N.A.; Anderson, K.P.; Calkins, H.; Hoch, D.; Goldberger, J.; Shalaby, A.; et al. Prophylactic defibrillator implantation in patients with nonischemic dilated cardiomyopathy. N. Engl. J. Med. 2004, 350, 2151-2158. [CrossRef]

40. Satoh, M.; Nakamura, M.; Akatsu, T.; Shimoda, Y.; Segawa, I.; Hiramori, K. Toll-like receptor 4 is expressed with enteroviral replication in myocardium from patients with dilated cardiomyopathy. Lab. Investig. 2004, 84, 173-181. [CrossRef]

41. Kubo, T.; Matsumura, Y.; Kitaoka, H.; Okawa, M.; Hirota, T.; Hamada, T.; Hitomi, N.; Hoshikawa, E.; Hayato, K.; Shimizu, Y.; et al. Improvement in prognosis of dilated cardiomyopathy in the elderly over the past 20 years. J. Cardiol. 2008, 52, 111-117. [CrossRef]

42. Heidecker, B.; Lamirault, G.; Kasper, E.K.; Wittstein, I.S.; Champion, H.C.; Breton, E.; Russell, S.D.; Hall, J.; Kittleson, M.M.; Baughman, K.L.; et al. The gene expression profile of patients with new-onset heart failure reveals important gender-specific differences. Eur. Heart J. 2010, 31, 1188-1196. [CrossRef] [PubMed]

43. Hamada, T.; Kubo, T.; Kitaoka, H.; Hirota, T.; Hoshikawa, E.; Hayato, K.; Shimizu, Y.; Okawa, M.; Yamasaki, N.; Matsumura, Y.; et al. Clinical features of the dilated phase of hypertrophic cardiomyopathy in comparison with those of dilated cardiomyopathy. Clin. Cardiol. 2010, 33, E24-E28. [CrossRef] [PubMed]

44. McNamara, D.M.; Starling, R.C.; Cooper, L.T.; Boehmer, J.P.; Mather, P.J.; Janosko, K.M.; Gorcsan, J.; Kip, K.E.; Dec, G.W.; Investigators, I. Clinical and demographic predictors of outcomes in recent onset dilated cardiomyopathy: Results of the IMAC (Intervention in Myocarditis and Acute Cardiomyopathy)-2 study. J. Am. Coll. Cardiol. 2011, 58, 1112-1118. [CrossRef] [PubMed]

45. Du, Y.; Yan, L.; Wang, J.; Zhan, W.; Song, K.; Han, X.; Li, X.; Cao, J.; Liu, H. ß1-Adrenoceptor autoantibodies from DCM patients

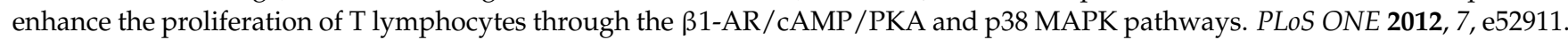
[CrossRef]

46. Castelli, G.; Fornaro, A.; Ciaccheri, M.; Dolara, A.; Troiani, V.; Tomberli, B.; Olivotto, I.; Gensini, G.F. Improving survival rates of patients with idiopathic dilated cardiomyopathy in Tuscany over 3 decades: Impact of evidence-based management. Circ. Heart Fail. 2013, 6, 913-921. [CrossRef]

47. Hirtle-Lewis, M.; Desbiens, K.; Ruel, I.; Rudzicz, N.; Genest, J.; Engert, J.C.; Giannetti, N. The genetics of dilated cardiomyopathy: A prioritized candidate gene study of LMNA, TNNT2, TCAP, and PLN. Clin. Cardiol. 2013, 36, 628-633. [CrossRef]

48. Dec, G.W. The natural history of acute dilated cardiomyopathy. Trans. Am. Clin. Clim. Assoc. 2014, 125, 76-86.

49. Merlo, M.; Pivetta, A.; Pinamonti, B.; Stolfo, D.; Zecchin, M.; Barbati, G.; Di Lenarda, A.; Sinagra, G. Long-term prognostic impact of therapeutic strategies in patients with idiopathic dilated cardiomyopathy: Changing mortality over the last 30 years. Eur. J. Heart Fail. 2014, 16, 317-324. [CrossRef]

50. Hazebroek, M.R.; Moors, S.; Dennert, R.; van den Wijngaard, A.; Krapels, I.; Hoos, M.; Verdonschot, J.; Merken, J.J.; de Vries, B.; Wolffs, P.F.; et al. Prognostic Relevance of Gene-Environment Interactions in Patients with Dilated Cardiomyopathy: Applying the MOGE(S) Classification. J. Am. Coll. Cardiol. 2015, 66, 1313-1323. [CrossRef] [PubMed]

51. Haas, J.; Frese, K.S.; Peil, B.; Kloos, W.; Keller, A.; Nietsch, R.; Feng, Z.; Müller, S.; Kayvanpour, E.; Vogel, B.; et al. Atlas of the clinical genetics of human dilated cardiomyopathy. Eur. Heart J. 2015, 36, 1123-1135a. [CrossRef]

52. Seidelmann, S.B.; Laur, O.; Hwa, J.; Depasquale, E.; Bellumkonda, L.; Sugeng, L.; Pomianowski, P.; Testani, J.; Chen, M.; McKenna, W.; et al. Familial dilated cardiomyopathy diagnosis is commonly overlooked at the time of transplant listing. J. Heart Lung Transpl. 2016, 35, 474-480. [CrossRef] [PubMed]

53. Halliday, B.P.; Gulati, A.; Ali, A.; Newsome, S.; Lota, A.; Tayal, U.; Vassiliou, V.S.; Arzanauskaite, M.; Izgi, C.; Krishnathasan, K.; et al. Sex-And age-based differences in the natural history and outcome of dilated cardiomyopathy. Eur. J. Heart Fail. 2018, 20, 1392-1400. [CrossRef]

54. Stojkovic, S.; Kaider, A.; Koller, L.; Brekalo, M.; Wojta, J.; Diedrich, A.; Demyanets, S.; Pezawas, T. GDF-15 is a better complimentary marker for risk stratification of arrhythmic death in non-ischaemic, dilated cardiomyopathy than soluble ST2. J. Cell Mol. Med. 2018, 22, 2422-2429. [CrossRef]

55. Charron, P.; Elliott, P.M.; Gimeno, J.R.; Caforio, A.L.P.; Kaski, J.P.; Tavazzi, L.; Tendera, M.; Maupain, C.; Laroche, C.; Rubis, P.; et al. The Cardiomyopathy Registry of the EURObservational Research Programme of the European Society of Cardiology: Baseline data and contemporary management of adult patients with cardiomyopathies. Eur. Heart J. 2018, 39, 1784-1793. [CrossRef]

56. Chen, C.; Liu, J.; Liu, Z.; He, X.; Yuan, X.; Ouyang, X.; Wang, L.; Li, X. Electrocardiogram signs of right ventricular hypertrophy may help identify pulmonary hypertension in patients with dilated cardiomyopathy. Int J. Cardiol. Heart Vasc. 2019, $22,61-66$. [CrossRef]

57. Kamisago, M.; Sharma, S.D.; DePalma, S.R.; Solomon, S.; Sharma, P.; McDonough, B.; Smoot, L.; Mullen, M.P.; Woolf, P.K.; Wigle, E.D.; et al. Mutations in sarcomere protein genes as a cause of dilated cardiomyopathy. N. Engl. J. Med. 2000, 343, 1688-1696. [CrossRef]

58. Lakdawala, N.K.; Dellefave, L.; Redwood, C.S.; Sparks, E.; Cirino, A.L.; Depalma, S.; Colan, S.D.; Funke, B.; Zimmerman, R.S.; Robinson, P.; et al. Familial dilated cardiomyopathy caused by an alpha-tropomyosin mutation: The distinctive natural history of sarcomeric dilated cardiomyopathy. J. Am. Coll. Cardiol. 2010, 55, 320-329. [CrossRef]

59. De Denus, S.; Mottet, F.; Korol, S.; Feroz Zada, Y.; Provost, S.; Mongrain, I.; Asselin, G.; Oussaid, E.; Busseuil, D.; Lettre, G.; et al. A genetic association study of heart failure: More evidence for the role of BAG3 in idiopathic dilated cardiomyopathy. Esc Heart Fail. 2020. [CrossRef] 
60. Fairweather, D.; Cooper, L.T.; Blauwet, L.A. Sex and gender differences in myocarditis and dilated cardiomyopathy. Curr. Probl. Cardiol. 2013, 38, 7-46. [CrossRef]

61. Herman, D.S.; Lam, L.; Taylor, M.R.; Wang, L.; Teekakirikul, P.; Christodoulou, D.; Conner, L.; DePalma, S.R.; McDonough, B.; Sparks, E.; et al. Truncations of titin causing dilated cardiomyopathy. N. Engl. J. Med. 2012, 366, 619-628. [CrossRef]

62. Pugh, T.J.; Kelly, M.A.; Gowrisankar, S.; Hynes, E.; Seidman, M.A.; Baxter, S.M.; Bowser, M.; Harrison, B.; Aaron, D.; Mahanta, L.M.; et al. The landscape of genetic variation in dilated cardiomyopathy as surveyed by clinical DNA sequencing. Genet. Med. 2014, 16, 601-608. [CrossRef] [PubMed]

63. McNally, E.M.; Golbus, J.R.; Puckelwartz, M.J. Genetic mutations and mechanisms in dilated cardiomyopathy. J. Clin. Investig. 2013, 123, 19-26. [CrossRef] [PubMed]

64. Belkaya, S.; Kontorovich, A.R.; Byun, M.; Mulero-Navarro, S.; Bajolle, F.; Cobat, A.; Josowitz, R.; Itan, Y.; Quint, R.; Lorenzo, L.; et al. Autosomal Recessive Cardiomyopathy Presenting as Acute Myocarditis. J. Am. Coll. Cardiol. 2017, 69, 1653-1665. [CrossRef] [PubMed]

65. Badorff, C.; Knowlton, K.U. Dystrophin disruption in enterovirus-induced myocarditis and dilated cardiomyopathy: From bench to bedside. Med. Microbiol. Immunol. 2004, 193, 121-126. [CrossRef]

66. Diegoli, M.; Grasso, M.; Favalli, V.; Serio, A.; Gambarin, F.I.; Klersy, C.; Pasotti, M.; Agozzino, E.; Scelsi, L.; Ferlini, A.; et al. Diagnostic work-up and risk stratification in X-linked dilated cardiomyopathies caused by dystrophin defects. J. Am. Coll. Cardiol. 2011, 58, 925-934. [CrossRef] [PubMed]

67. Myers, J.M.; Fairweather, D.; Huber, S.A.; Cunningham, M.W. Autoimmune myocarditis, valvulitis, and cardiomyopathy. Curr. Protoc. Immunol. 2013, 14, 11-51. [CrossRef] [PubMed]

68. Myers, J.M.; Cooper, L.T.; Kem, D.C.; Stavrakis, S.; Kosanke, S.D.; Shevach, E.M.; Fairweather, D.; Stoner, J.A.; Cox, C.J.; Cunningham, M.W. Cardiac myosin-Th17 responses promote heart failure in human myocarditis. JCI Insight 2016, 1. [CrossRef] [PubMed]

69. Coronado, M.J.; Bruno, K.A.; Blauwet, L.A.; Tschope, C.; Cunningham, M.W.; Pankuweit, S.; van Linthout, S.; Jeon, E.S.; McNamara, D.M.; Krejci, J.; et al. Elevated Sera sST2 Is Associated with Heart Failure in Men $\leq 50$ Years Old with Myocarditis. J. Am. Heart Assoc. 2019, 8, e008968. [CrossRef]

70. Kindermann, I.; Kindermann, M.; Kandolf, R.; Klingel, K.; Bultmann, B.; Muller, T.; Lindinger, A.; Bohm, M. Predictors of outcome in patients with suspected myocarditis. Circulation 2008, 118, 639-648. [CrossRef]

71. Fatkin, D.; MacRae, C.; Sasaki, T.; Wolff, M.R.; Porcu, M.; Frenneaux, M.; Atherton, J.; Vidaillet, H.J., Jr.; Spudich, S.; De Girolami, U.; et al. Missense mutations in the rod domain of the lamin A/C gene as causes of dilated cardiomyopathy and conduction-system disease. N. Engl. J. Med. 1999, 341, 1715-1724. [CrossRef]

72. Norton, N.; Li, D.; Rieder, M.J.; Siegfried, J.D.; Rampersaud, E.; Zuchner, S.; Mangos, S.; Gonzalez-Quintana, J.; Wang, L.; McGee, S.; et al. Genome-wide studies of copy number variation and exome sequencing identify rare variants in BAG3 as a cause of dilated cardiomyopathy. Am. J. Hum. Genet. 2011, 88, 273-282. [CrossRef] [PubMed]

73. Arimura, T.; Ishikawa, T.; Nunoda, S.; Kawai, S.; Kimura, A. Dilated cardiomyopathy-associated BAG3 mutations impair Z-disc assembly and enhance sensitivity to apoptosis in cardiomyocytes. Hum. Mutat. 2011, 32, 1481-1491. [CrossRef] [PubMed]

74. Duboscq-Bidot, L.; Xu, P.; Charron, P.; Neyroud, N.; Dilanian, G.; Millaire, A.; Bors, V.; Komajda, M.; Villard, E. Mutations in the Z-band protein myopalladin gene and idiopathic dilated cardiomyopathy. Cardiovasc. Res. 2008, 77, 118-125. [CrossRef] [PubMed]

75. Garcia-Pavia, P.; Syrris, P.; Salas, C.; Evans, A.; Mirelis, J.G.; Cobo-Marcos, M.; Vilches, C.; Bornstein, B.; Segovia, J.; AlonsoPulpon, L.; et al. Desmosomal protein gene mutations in patients with idiopathic dilated cardiomyopathy undergoing cardiac transplantation: A clinicopathological study. Heart 2011, 97, 1744-1752. [CrossRef]

76. Begay, R.L.; Tharp, C.A.; Martin, A.; Graw, S.L.; Sinagra, G.; Miani, D.; Sweet, M.E.; Slavov, D.B.; Stafford, N.; Zeller, M.J.; et al. FLNC gene splice mutations cause dilated cardiomyopathy. JACC Basic Transl. Sci. 2016, 1, 344-359. [CrossRef]

77. Brauch, K.M.; Karst, M.L.; Herron, K.J.; de Andrade, M.; Pellikka, P.A.; Rodeheffer, R.J.; Michels, V.V.; Olson, T.M. Mutations in ribonucleic acid binding protein gene cause familial dilated cardiomyopathy. J. Am. Coll. Cardiol. 2009, 54, 930-941. [CrossRef]

78. McNair, W.P.; Ku, L.; Taylor, M.R.; Fain, P.R.; Dao, D.; Wolfel, E.; Mestroni, L.; Familial Cardiomyopathy Registry Research, G. SCN5A mutation associated with dilated cardiomyopathy, conduction disorder, and arrhythmia. Circulation 2004, 110, $2163-2167$. [CrossRef]

79. Olson, T.M.; Michels, V.V.; Ballew, J.D.; Reyna, S.P.; Karst, M.L.; Herron, K.J.; Horton, S.C.; Rodeheffer, R.J.; Anderson, J.L. Sodium channel mutations and susceptibility to heart failure and atrial fibrillation. JAMA 2005, 293, 447-454. [CrossRef]

80. Olson, T.M.; Kishimoto, N.Y.; Whitby, F.G.; Michels, V.V. Mutations that alter the surface charge of alpha-tropomyosin are associated with dilated cardiomyopathy. J. Mol. Cell. Cardiol. 2001, 33, 723-732. [CrossRef]

81. Hershberger, R.E.; Morales, A.; Siegfried, J.D. Clinical and genetic issues in dilated cardiomyopathy: A review for genetics professionals. Genet. Med. 2010, 12, 655-667. [CrossRef]

82. Liu, L.Y.; Schaub, M.A.; Sirota, M.; Butte, A.J. Sex differences in disease risk from reported genome-wide association study findings. Hum. Genet. 2012, 131, 353-364. [CrossRef]

83. Haddad, G.E.; Saunders, L.J.; Crosby, S.D.; Carles, M.; del Monte, F.; King, K.; Bristow, M.R.; Spinale, F.G.; Macgillivray, T.E.; Semigran, M.J.; et al. Human cardiac-specific cDNA array for idiopathic dilated cardiomyopathy: Sex-related differences. Physiol. Genom. 2008, 33, 267-277. [CrossRef] 
84. Stefanelli, C.B.; Rosenthal, A.; Borisov, A.B.; Ensing, G.J.; Russell, M.W. Novel troponin T mutation in familial dilated cardiomyopathy with gender-dependant severity. Mol. Genet. Metab. 2004, 83, 188-196. [CrossRef] [PubMed]

85. Crispell, K.A.; Wray, A.; Ni, H.; Nauman, D.J.; Hershberger, R.E. Clinical profiles of four large pedigrees with familial dilated cardiomyopathy: Preliminary recommendations for clinical practice. J. Am. Coll. Cardiol. 1999, 34, 837-847. [CrossRef]

86. Kushner, J.D.; Nauman, D.; Burgess, D.; Ludwigsen, S.; Parks, S.B.; Pantely, G.; Burkett, E.; Hershberger, R.E. Clinical characteristics of 304 kindreds evaluated for familial dilated cardiomyopathy. J. Card Fail. 2006, 12, 422-429. [CrossRef] [PubMed]

87. Van Spaendonck-Zwarts, K.Y.; van Rijsingen, I.A.; van den Berg, M.P.; Lekanne Deprez, R.H.; Post, J.G.; van Mil, A.M.; Asselbergs, F.W.; Christiaans, I.; van Langen, I.M.; Wilde, A.A.; et al. Genetic analysis in 418 index patients with idiopathic dilated cardiomyopathy: Overview of 10 years' experience. Eur. J. Heart Fail. 2013, 15, 628-636. [CrossRef] [PubMed]

88. Franaszczyk, M.; Chmielewski, P.; Truszkowska, G.; Stawinski, P.; Michalak, E.; Rydzanicz, M.; Sobieszczanska-Malek, M.; Pollak, A.; Szczygieł, J.; Kosinska, J.; et al. Titin truncating variants in dilated cardiomyopathy-Prevalence and genotype-phenotype correlations. PLoS ONE 2017, 12, e0169007. [CrossRef]

89. Meyer, S.; van der Meer, P.; van Tintelen, J.P.; van den Berg, M.P. Sex differences in cardiomyopathies. Eur. J. Heart Fail. 2014, 16, 238-247. [CrossRef]

90. Pelliccia, F.; Limongelli, G.; Autore, C.; Gimeno-Blanes, J.R.; Basso, C.; Elliott, P. Sex-related differences in cardiomyopathies. Int. J. Cardiol. 2019, 286, 239-243. [CrossRef]

91. Richardson, P.; McKenna, W.; Bristow, M.; Maisch, B.; Mautner, B.; O'Connell, J.; Olsen, E.; Thiene, G.; Goodwin, J.; Gyarfas, I.; et al. Report of the 1995 World Health Organization/International Society and Federation of Cardiology Task Force on the Definition and Classification of cardiomyopathies. Circulation 1996, 93, 841-842. [CrossRef]

92. Noutsias, M.; Rohde, M.; Goldner, K.; Block, A.; Blunert, K.; Hemaidan, L.; Hummel, M.; Blohm, J.H.; Lassner, D.; Kuhl, U.; et al. Expression of functional T-cell markers and T-cell receptor Vbeta repertoire in endomyocardial biopsies from patients presenting with acute myocarditis and dilated cardiomyopathy. Eur. J. Heart Fail. 2011, 13, 611-618. [CrossRef] [PubMed]

93. Ammirati, E.; Frigerio, M.; Adler, E.D.; Basso, C.; Birnie, D.H.; Brambatti, M.; Friedrich, M.G.; Klingel, K.; Lehtonen, J.; Moslehi, J.J.; et al. Management of acute myocarditis and chronic inflammatory cardiomyopathy: An expert consensus document. Circ. Heart Fail. 2020, 13, e007405. [CrossRef]

94. Kang, M.; An, J. Viral myocarditis. In StatPearls; StatPearls Publishing: Treasure Island, FL, USA, 2021.

95. Nguyen, T.; Waseem, M. Chagas disease. In StatPearls; StatPearls Publishing: Treasure Island, FL, USA, 2021.

96. Kaya, Z.; Afanasyeva, M.; Wang, Y.; Dohmen, K.M.; Schlichting, J.; Tretter, T.; Fairweather, D.; Holers, V.M.; Rose, N.R. Contribution of the innate immune system to autoimmune myocarditis: A role for complement. Nat. Immunol. 2001, 2, 739-745. [CrossRef] [PubMed]

97. Fairweather, D.; Frisancho-Kiss, S.; Njoku, D.B.; Nyland, J.F.; Kaya, Z.; Yusung, S.A.; Davis, S.E.; Frisancho, J.A.; Barrett, M.A.; Rose, N.R. Complement receptor 1 and 2 deficiency increases coxsackievirus B3-induced myocarditis, dilated cardiomyopathy, and heart failure by increasing macrophages, IL-1beta, and immune complex deposition in the heart. J. Immunol. 2006, 176, 3516-3524. [CrossRef] [PubMed]

98. Cooper, L.T., Jr.; Onuma, O.K.; Sagar, S.; Oberg, A.L.; Mahoney, D.W.; Asmann, Y.W.; Liu, P. Genomic and proteomic analysis of myocarditis and dilated cardiomyopathy. Heart Fail. Clin. 2010, 6, 75-85. [CrossRef]

99. Fairweather, D.; Yusung, S.; Frisancho, S.; Barrett, M.; Gatewood, S.; Steele, R.; Rose, N.R. IL-12 receptor beta 1 and Toll-like receptor 4 increase IL-1 beta- and IL-18-associated myocarditis and coxsackievirus replication. J. Immunol. 2003, 170, 4731-4737. [CrossRef]

100. Frisancho-Kiss, S.; Davis, S.E.; Nyland, J.F.; Frisancho, J.A.; Cihakova, D.; Barrett, M.A.; Rose, N.R.; Fairweather, D. Cutting edge: Cross-regulation by TLR4 and T cell Ig mucin-3 determines sex differences in inflammatory heart disease. J. Immunol. 2007, 178, 6710-6714. [CrossRef] [PubMed]

101. Coronado, M.J.; Brandt, J.E.; Kim, E.; Bucek, A.; Bedja, D.; Abston, E.D.; Shin, J.; Gabrielson, K.L.; Mitzner, W.; Fairweather, D. Testosterone and interleukin- $1 \beta$ increase cardiac remodeling during coxsackievirus B3 myocarditis via serpin A 3n. Am. J. Physiol. Heart Circ. Physiol. 2012, 302, H1726-H1736. [CrossRef]

102. Fairweather, D.; Frisancho-Kiss, S.; Yusung, S.A.; Barrett, M.A.; Davis, S.E.; Gatewood, S.J.; Njoku, D.B.; Rose, N.R. Interferongamma protects against chronic viral myocarditis by reducing mast cell degranulation, fibrosis, and the profibrotic cytokines transforming growth factor-beta 1, interleukin-1 beta, and interleukin-4 in the heart. Am. J. Pathol. 2004, 165, 1883-1894. [CrossRef]

103. Fairweather, D.; Frisancho-Kiss, S.; Yusung, S.A.; Barrett, M.A.; Davis, S.E.; Steele, R.A.; Gatewood, S.J.; Rose, N.R. IL-12 protects against coxsackievirus B3-induced myocarditis by increasing IFN-gamma and macrophage and neutrophil populations in the heart. J. Immunol. 2005, 174, 261-269. [CrossRef] [PubMed]

104. Abston, E.D.; Coronado, M.J.; Bucek, A.; Bedja, D.; Shin, J.; Kim, J.B.; Kim, E.; Gabrielson, K.L.; Georgakopoulos, D.; Mitzner, W.; et al. Th2 regulation of viral myocarditis in mice: Different roles for TLR3 versus TRIF in progression to chronic disease. Clin. Dev. Immunol. 2012, 2012, 129486. [CrossRef] [PubMed]

105. Abston, E.D.; Coronado, M.J.; Bucek, A.; Onyimba, J.A.; Brandt, J.E.; Frisancho, J.A.; Kim, E.; Bedja, D.; Sung, Y.K.; Radtke, A.J.; et al. TLR3 deficiency induces chronic inflammatory cardiomyopathy in resistant mice following coxsackievirus B3 infection: Role for IL-4. Am. J. Physiol. Regul. Integr. Comp. Physiol. 2013, 304, R267-R277. [CrossRef] [PubMed]

106. Afanasyeva, M.; Wang, Y.; Kaya, Z.; Park, S.; Zilliox, M.J.; Schofield, B.H.; Hill, S.L.; Rose, N.R. Experimental autoimmune myocarditis in A/J mice is an interleukin-4-dependent disease with a Th2 phenotype. Am. J. Pathol. 2001, 159, 193-203. [CrossRef] 
107. Diny, N.L.; Baldeviano, G.C.; Talor, M.V.; Barin, J.G.; Ong, S.; Bedja, D.; Hays, A.G.; Gilotra, N.A.; Coppens, I.; Rose, N.R.; et al. Eosinophil-derived IL-4 drives progression of myocarditis to inflammatory dilated cardiomyopathy. J. Exp. Med. 2017, 214, 943-957. [CrossRef] [PubMed]

108. Wu, L.; Ong, S.; Talor, M.V.; Barin, J.G.; Baldeviano, G.C.; Kass, D.A.; Bedja, D.; Zhang, H.; Sheikh, A.; Margolick, J.B.; et al. Cardiac fibroblasts mediate IL-17A-driven inflammatory dilated cardiomyopathy. J. Exp. Med. 2014, 211, 1449-1464. [CrossRef] [PubMed]

109. Abston, E.D.; Barin, J.G.; Cihakova, D.; Bucek, A.; Coronado, M.J.; Brandt, J.E.; Bedja, D.; Kim, J.B.; Georgakopoulos, D.; Gabrielson, K.L.; et al. IL-33 independently induces eosinophilic pericarditis and cardiac dilation: ST2 improves cardiac function. Circ. Heart Fail. 2012, 5, 366-375. [CrossRef]

110. Fairweather, D.; Petri, M.A.; Coronado, M.J.; Cooper, L.T. Autoimmune heart disease: Role of sex hormones and autoantibodies in disease pathogenesis. Expert Rev. Clin. Immunol. 2012, 8, 269-284. [CrossRef]

111. Fairweather, D.; Frisancho-Kiss, S.; Gatewood, S.; Njoku, D.; Steele, R.; Barrett, M.; Rose, N.R. Mast cells and innate cytokines are associated with susceptibility to autoimmune heart disease following coxsackievirus B3 infection. Autoimmunity 2004, 37 , 131-145. [CrossRef]

112. Tschope, C.; Muller, I.; Xia, Y.; Savvatis, K.; Pappritz, K.; Pinkert, S.; Lassner, D.; Heimesaat, M.M.; Spillmann, F.; Miteva, K.; et al. NOD2 (Nucleotide-Binding Oligomerization Domain 2) is a major pathogenic mediator of coxsackievirus B3-Induced myocarditis. Circ. Heart Fail. 2017, 10. [CrossRef]

113. Fuse, K.; Chan, G.; Liu, Y.; Gudgeon, P.; Husain, M.; Chen, M.; Yeh, W.C.; Akira, S.; Liu, P.P. Myeloid differentiation factor-88 plays a crucial role in the pathogenesis of Coxsackievirus B3-induced myocarditis and influences type I interferon production. Circulation 2005, 112, 2276-2285. [CrossRef]

114. Epelman, S.; Liu, P.P.; Mann, D.L. Role of innate and adaptive immune mechanisms in cardiac injury and repair. Nat. Rev. Immunol. 2015, 15, 117-129. [CrossRef]

115. Siegel, R.L.; Miller, K.D.; Fuchs, H.E.; Jemal, A. Cancer statistics, 2021. Ca Cancer J. Clin. 2021, 71, 7-33. [CrossRef] [PubMed]

116. Cardinale, D.; Colombo, A.; Bacchiani, G.; Tedeschi, I.; Meroni, C.A.; Veglia, F.; Civelli, M.; Lamantia, G.; Colombo, N.; Curigliano, G.; et al. Early detection of anthracycline cardiotoxicity and improvement with heart failure therapy. Circulation 2015, 131, 1981-1988. [CrossRef] [PubMed]

117. Perez, I.E.; Taveras Alam, S.; Hernandez, G.A.; Sancassani, R. Cancer therapy-related cardiac dysfunction: An overview for the clinician. Clin. Med. Insights Cardiol. 2019, 13, 1179546819866445. [CrossRef] [PubMed]

118. Zhang, S.; Liu, X.; Bawa-Khalfe, T.; Lu, L.S.; Lyu, Y.L.; Liu, L.F.; Yeh, E.T. Identification of the molecular basis of doxorubicininduced cardiotoxicity. Nat. Med. 2012, 18, 1639-1642. [CrossRef] [PubMed]

119. Di Florio, D.N.; Sin, J.; Coronado, M.J.; Atwal, P.S.; Fairweather, D. Sex differences in inflammation, redox biology, mitochondria and autoimmunity. Redox Biol. 2020, 31, 101482. [CrossRef] [PubMed]

120. Cowan, J.R.; Salyer, L.; Wright, N.T.; Kinnamon, D.D.; Amaya, P.; Jordan, E.; Bamshad, M.J.; Nickerson, D.A.; Hershberger, R.E. SOS1 Gain-of-Function Variants in Dilated Cardiomyopathy. Circ. Genom. Precis. Med. 2020, 13, e002892. [CrossRef]

121. Melchert, R.B.; Welder, A.A. Cardiovascular effects of androgenic-anabolic steroids. Med. Sci Sports Exerc 1995, $27,1252-1262$. [CrossRef]

122. Scheuer, J.; Malhotra, A.; Schaible, T.F.; Capasso, J. Effects of gonadectomy and hormonal replacement on rat hearts. Circ. Res. 1987, 61, 12-19. [CrossRef]

123. Vitale, C.; Mendelsohn, M.E.; Rosano, G.M. Gender differences in the cardiovascular effect of sex hormones. Nat. Rev. Cardiol. 2009, 6, 532-542. [CrossRef]

124. Calippe, B.; Douin-Echinard, V.; Delpy, L.; Laffargue, M.; Lelu, K.; Krust, A.; Pipy, B.; Bayard, F.; Arnal, J.F.; Guery, J.C.; et al. 17Beta-estradiol promotes TLR4-triggered proinflammatory mediator production through direct estrogen receptor alpha signaling in macrophages in vivo. J. Immunol. 2010, 185, 1169-1176. [CrossRef]

125. Kraft, L.; Erdenesukh, T.; Sauter, M.; Tschope, C.; Klingel, K. Blocking the IL-1beta signalling pathway prevents chronic viral myocarditis and cardiac remodeling. Basic Res. Cardiol. 2019, 114, 11. [CrossRef] [PubMed]

126. Xu, Y.; Arenas, I.A.; Armstrong, S.J.; Plahta, W.C.; Xu, H.; Davidge, S.T. Estrogen improves cardiac recovery after ischemia/reperfusion by decreasing tumor necrosis factor-alpha. Cardiovasc. Res. 2006, 69, 836-844. [CrossRef] [PubMed]

127. Kararigas, G.; Fliegner, D.; Gustafsson, J.A.; Regitz-Zagrosek, V. Role of the estrogen/estrogen-receptor-beta axis in the genomic response to pressure overload-induced hypertrophy. Physiol. Genom. 2011, 43, 438-446. [CrossRef]

128. Planavila, A.; Laguna, J.C.; Vazquez-Carrera, M. Nuclear factor-kappaB activation leads to down-regulation of fatty acid oxidation during cardiac hypertrophy. J. Biol. Chem. 2005, 280, 17464-17471. [CrossRef]

129. Blanco, J.G.; Sun, C.L.; Landier, W.; Chen, L.; Esparza-Duran, D.; Leisenring, W.; Mays, A.; Friedman, D.L.; Ginsberg, J.P.; Hudson, M.M.; et al. Anthracycline-related cardiomyopathy after childhood cancer: Role of polymorphisms in carbonyl reductase genes-A report from the Children's Oncology Group. J. Clin. Oncol. 2012, 30, 1415-1421. [CrossRef] [PubMed] 